\title{
Accounting for globalization: The Journal of Management Control on its way to a global reach
}

\author{
Thomas W. Guenther
}

(C) Springer-Verlag Berlin Heidelberg 2013

In 2011 the Journal of Management Control (JoMaC), which draws from a 20 year long experience of a specialized German-speaking journal, entered the global market of accounting journals specialized in the area of management control and related fields.

Two years later, it is time to look back and account for what we achieved so far. In 2012, our authors came from 18 different countries all around the world and reviewers covered 11 different countries of origin. Our journal is now available in more than 6,900 institutions all around the world. Fulltext downloads are up $106 \%$ since going global. Full-text article requests are coming from North America (15\%), Asia-Pacific (15\%), South America (5\%), Africa (5\%), Germany (46\%) and other European countries $(14 \%)$. This is good news for our authors as they can offer their work to the global scientific community. Average turnaround time to decision on final acceptance is 152 days. Of course, the time to rejection is to the detriment of affected authors faster. The acceptance rate for submissions handed in 2012 was $20.4 \%$.

At January 1st, 2013, I took over the function as managing editor of JoMaC. I appreciate the great support and trust of my co-editors. I will do my very best to further develop our Journal of Management Control. We would like to thank Uwe Goetze who was in charge of managing editor for many years now and who contributed to build the reputation of JoMaC by his endurance in taking care of both authors and reviewers.

At the same time, one of the founders of the preceding Zeitschrift für Planung und Unternehmenssteuerung, our distinguished colleague Juergen Bloech, retired from the board of editors. We appreciate his vision to create a specialized management control and planning journal and his long-term sustainable commitment for our journal. We will certainly miss him.

T. W. Guenther $(\bowtie)$

Journal of Management Control, Technische Universität Dresden, 01062 Dresden, Germany

e-mail: thomas.guenther@tu-dresden.de 
Starting in 2013 we further expanded our editorial board by distinguished and well-known scholars:

Prof. Markus Arnold, University of Bern, Switzerland, Prof. Daria Battini, University of Padua, Italy, Prof. Alexander Brüggen, Maastricht University, The Netherlands, Prof. Malte Fliedner, University of Hamburg, Germany, Prof. Martin Messner, University of Innsbruck, Austria, Prof. Gerhard Speckbacher, Vienna University of Economics and Business, Austria, Prof. Carl Marcus Wallenburg, WHU-Otto Beisheim School of Management, Vallendar, Germany, Prof. Andreas Wömpener, University Duisburg-Essen, Germany.

We are sure that the extended editorial board will give us guidance and support by their specific expertise to further develop our journal.

As in 2011, the editors also voted for JoMaC's Best Reviewer Award 2012. This year for outstanding support of authors and careful guidance to further develop papers the award goes to:

Best reviewer award 2012: Bart Dierynch, Tilburg University, The Netherlands

Runners up are: Ivo Tavkov, Georgia State University, United States

Matthias Mahlendorf, WHU Otto Beisheim School of Management, Vallendar, Germany direct below Mahlendorf

In 2012, the following reviewers in alphabetical order devoted their precious time for reviews of submitted papers in JoMaC (reviews finished in 2012):

\begin{tabular}{|c|c|c|c|}
\hline Prof. Dr. & Markus C. & Arnold & University of Bern, Switzerland \\
\hline Mrs. & Anna & Azzi & University of Padova, Italy \\
\hline Prof. Dr. & Nils & Boysen & University Jena, Germany \\
\hline Prof. Dr. & Alexander & Brüggen & Maastricht University, The Netherlands \\
\hline Prof. Dr. & Michael & Burkert & HEC Lausanne, Switzerland \\
\hline Prof. Dr. & Udo & Buscher & TU Dresden, Germany \\
\hline Dr. & Yuval & Cohen & The Open University of Israel, Israel \\
\hline Prof. Dr. & Michela & Cordazzo & Free University of Bolzano, Italy \\
\hline Prof. & José Crespo & de Carvalho & ISCTE Business School, Lisabon, Portugal \\
\hline Dr. & Bart & Dierynck & Tilburg University, The Netherlands \\
\hline Dr. & Simon & Emde & University Jena, Germany \\
\hline Mr. & Christoph & Feichter & Maastricht University, The Netherlands \\
\hline Prof. Dr. & Malte & Fliedner & University of Hamburg, Germany \\
\hline Prof. Dr. & Carl-Christian & Freidank & University of Hamburg, Germany \\
\hline PD Dr. & Andrea & Fried & Chemnitz University of Technology, Germany \\
\hline Prof. Dr. & Robert & Gillenkirch & Osnabrück University, Germany \\
\hline Prof. Dr. & Roland & Gleich & European Business School, Wiesbaden, Germany \\
\hline Prof. Dr. & Uwe & Götze & Chemnitz University of Technology, Germany \\
\hline Prof. Dr. & Thomas & Günther & TU Dresden, Germany \\
\hline Prof. Dr. & Edeltraud & Günther & TU Dresden, Germany \\
\hline Prof. Dr. & Michael & Hinz & Chemnitz University of Technology, Germany \\
\hline Prof. Dr. & Michael & Höck & TU Bergakademie Freiberg, Freiberg, Germany \\
\hline Prof. Dr. & Bernd & Hüfner & University Jena, Germany \\
\hline Prof. Dr. & Jochen & Hundsdoerfer & Freie Universität Berlin, Germany \\
\hline Prof. Dr. & Joachim & Käschel & Chemnitz University of Technology, Germany \\
\hline Dr. & Thorsten & Knauer & The University of Muenster, Germany \\
\hline Dr. & Stephan & Kramer & $\begin{array}{l}\text { Rotterdam School of Management, Erasmus University, } \\
\text { The Netherlands }\end{array}$ \\
\hline JProf. Dr. & Maik & Lachmann & TU Dortmund, Germany \\
\hline
\end{tabular}




\begin{tabular}{|c|c|c|c|}
\hline Prof. Dr. & Stephan & Lengsfeld & University of Freiburg, Germany \\
\hline Dr. & Stefan & Linder & ESSEC Business School, Paris, France \\
\hline Prof. Dr. & Victor & Maas & $\begin{array}{l}\text { Rotterdam School of Management, Erasmus University, } \\
\text { The Netherlands }\end{array}$ \\
\hline JProf. Dr. & Matthias & Mahlendorf & $\begin{array}{l}\text { WHU, Otto Beisheim School of Management, Vallendar, } \\
\text { Germany }\end{array}$ \\
\hline Prof. & Stijn & Masschelein & The University of Western Australia, Australia \\
\hline Prof. Dr. & Klaus & Möller & University of St. Gallen, Switzerland \\
\hline Prof. Dr. & Stefan & Müller & $\begin{array}{l}\text { Helmut Schmidt University, University of the Federal } \\
\text { Armed Forces, Hamburg, Germany }\end{array}$ \\
\hline Prof. Dr. & Wolfgang & Ossadnik & Osnabrück University, Germany \\
\hline Dr. & Cristiana & Parisi & Copenhagen Business School, Copenhagen, Danmark \\
\hline Prof. Dr. & Hans-Jürgen & Prehm & $\begin{array}{l}\text { Jade University of Applied Science, Wilhelmshaven, } \\
\text { Germany }\end{array}$ \\
\hline Prof. Dr. & Roland & Rollberg & University of Greifswald, Germany \\
\hline Prof. Dr. & Utz & Schaeffer & $\begin{array}{l}\text { WHU, Otto Beisheim School of Management, Vallendar, } \\
\text { Germany }\end{array}$ \\
\hline Dr. & Walter & Schmitting & The University of Muenster, Germany \\
\hline Dr. & Johannes & Siebert & University of Bayreuth, Germany \\
\hline Prof. Dr. & Ulrike & Stefani & University of Konstanz, Germany \\
\hline Prof. & Ivo D. & Tafkov & $\begin{array}{l}\text { J. Mack Robinson College of Business, Georgia State } \\
\text { University, USA }\end{array}$ \\
\hline Dr. & Patrick & Velte & University of Hamburg, Germany \\
\hline Prof. Dr. & Friederike & Wall & Alpen-Adria-University Klagenfurt, Austria \\
\hline Prof. Dr. & Gianfranco & Walsh & University Jena, Germany \\
\hline Prof. Dr. & Grit & Walther & RWTH Aachen University, Germany \\
\hline Prof. Dr. & Andreas & Wömpener & University of Duisburg-Essen, Germany \\
\hline
\end{tabular}

The editors of the Journal of Management Control acknowledge the great support of our team of reviewers, who give valuable comments and recommendations based on their scholarly experience to authors and, thus, tremendously supported the Journal of Management Control.

Looking back on what we have achieved so far the editors of the Journal of Management Control are confident that we will manage the challenges ahead and that our baby, the Journal of Management Control, will grow into the global market of academic excellence. 